\title{
Skin and mucosa in patients with solid organ transplant: risks and precautions
}

\section{Solid organ transplantasyonlu hastalarda deri ve mukoza: riskler ve önlemler}

\author{
Zuleyha Ozgen ${ }^{1}$, Elif Comert Ozer ${ }^{1}$ \\ ${ }^{1}$ Dept. of Dermatology, Marmara University School of Medicine, Istanbul, Turkey
}

\begin{abstract}
In solid organ transplant patients; many skin diseases are more common and more resistant to treatment, because of the multiple medications and immunosuppressive therapies. In order to increase survival, it is important to evaluate and follow these patients with a multidisciplinary team including the dermatologist. In this review, the following are reviewed along with the current literature; skin and mucosa findings due to immunosuppressive therapies used in solid organ transplant patients, inflammatory, infectious and neoplastic skin diseases which are increased compared to the normal population, and the important points in diagnosis and treatment of these diseases.
\end{abstract}

Key words: organ transplantation, immunosupression, skin neoplasm, drug reaction, opportunistic infection, infection prevention

O̊zet

Solid organ nakli hastalarının kullandığı çoklu ilaçlar ve immünsupresif tedaviler nedeniyle birçok deri hastalığı bu hasta grubunda daha sık görülmekte ve tedaviye daha dirençli seyretmektedir. Hastaların, sağ kalımlarını arttırmak amacı ile içerisinde dermatoloji uzmanının da bulunduğu bir ekip tarafından multidisipliner olarak değerlendirilmesi ve takip edilmesi önemlidir. Bu derlemede solid organ nakli hastalarında kullanılan immünsupresif tedavilere bağlı görülen deri ve mukoza bulguları, topluma göre sıklı̆̆ında artış gözlenen enflamatuar, enfeksiyöz ve neoplastik deri hastalıkları ile bu hastalıkların tanı ve tedavisinde dikkat edilmesi gereken noktalar güncel literatür eşliğinde gözden geçirilmiştir.

Key words: organ nakli, immünsupresyon, deri kanserleri, ilaç reaksiyonları, fırsatçı enfeksiyonlar, enfeksiyon önlemleri

\section{Introduction}

Solid organ transplant has various effects on skin, primarily because of treatment-related immunosuppression. Hemodynamics and immunosuppressive therapies of patients with heart and other solid organ transplant are similar. Since heart transplant has been applied to a more limited number of patients all over the world, the

Corresponding author: Elif Comert, Marmara Universitesi, Pendik Egitim ve Arastirma Hastanesi, Dermatoloji Anabilim Dali Fevzi Cakmak Mah, Mimar Sinan Cad. No:41 34899 Pendik, Istanbul, Turkey, Phone: +90 216657 0606, E-mail: elifcomertt@gmail.com Received: 1 July 2020 Accepted: 12 December 2020

Conflicts of Interest: None

Funding: None

How to cite this article: Ozgen Z, Comert E. Skin and mucosa in the patients with solid organ transplant: risks and precautions. Mucosa 2020;3:83-92 
skin findings of these patients are generally evaluated together with the skin findings observed in other solid organ transplants. In the literature, there are also cross-sectional studies reporting that these changes are more frequent, earlier and more severe in patients undergoing heart transplant than in patients with other solid organ transplants. ${ }^{1,2}$ It is suggested that the dose of immunosuppressive treatment used in heart transplant is higher than the dose used in other solid organ transplants. In this review, similar to the literature, general knowledge about solid organ transplantation and experiences of kidney transplant patients have been utilized.

To improve the survival and quality of life of organ transplant patients, these patients should be evaluated and monitored by a team including the experienced surgical, oncology, internal medicine, cardiology and dermatology specialists, as well as the surgical transplant team before and after the transplant. Moreover, according to the current developments, cooperation with the disciplines of microbiology and dermatopathology will be very essential and useful in the diagnosis. Multidisciplinary evaluation and interdepartmental cooperation are an important element while organ transplant patients are evaluated. In this review we try to give some important and basic concepts of dermatological evaluation of transplant recipients from pre-transplantational days to the rest of the patient's life after transplant.

\section{Dermatological evaluation of organ}

\section{transplant patients}

\section{Before transplantation}

The dermatological evaluations of the patients should be started before transplant and then repeated at certain time intervals depending on the patient's current condition and risk factors. The full physical examinations of the patients should include the scalp, oral and genital mucosa. The systemic diseases and their immunosuppressive and other treatments should also be noted. The current risk factors for skin cancers should be evaluated. Metastatic basal cell carcinoma
(BCC), squamous cell carcinoma (SCC), merkel cell carcinoma (MCC) and stage 2, 3, 4 melanoma detection, even in remission, may be contraindications for organ transplant. ${ }^{3}$ The decision of transfer in highrisk SCC, stage 1 melanoma, non-metastatic MCC, Kaposi Sarcoma and other cancers of the skin should be individually determined according to the risk status of each patient. In cases where there is no contraindication, it is important to arrange the treatment and follow-up and to plan the correct time for transplant.

It is suggested that patients should be evaluated in terms of herpes, varicella, and other infections and their pretransplant prophylaxis and/or vaccination according to their serology. ${ }^{4}$ The patients should be treated if they have warts detected in their examination. Also, if there is another infection other than warts, such as viral, fungal or bacterial, they should be treated as well before the transplant.

\section{After transplantation}

It is important to educate patients about sun protection, providing educational brochures and give information about self-examination for reducing the risk of skin cancer after transplantation and early diagnosis. It has been shown that patients who followed up by experts who are experienced in this field, have higher quality of life and early diagnosis. ${ }^{5}$

After transplant, it is recommended that the patients with no history of skin cancer and normal skin examination need to have dermatological examinations every 12 months; patients with one BCC or a history, five or fewer actinic keratoses, and one dysplastic nevus need to be examined every six months; patients with more than 10 actinic keratoses, multiple dysplastic nevi, recurrent and multiple BCC, SCC and melanoma or a history, should be examined in every three months. ${ }^{6}$

The effects of solid organ transplant on the skin may be examined under four main headings: inflammatory, infectious, direct toxic effects of used immunosuppressive drugs and neoplastic changes (Table 1). 


\section{Inflammatory skin lesions}

Seborrheic dermatitis and pityrosporum folliculitis are more common and more diffuse in organ recipients due to immunosuppressive treatments and increased

Table 1. Effects of solid organ transplantation on the skin and mucosa

\begin{tabular}{l} 
Inflammatory skin lesions \\
Infectious skin lesions \\
\hline Side effects of immunosuppressive drugs on skin and \\
appendages \\
Neoplastic skin lesions \\
Skin appendage tumors \\
Melanoma \\
Kaposi's sarcoma \\
Soft tissue tumors-sarcomas \\
SCC and its precursors \\
BCC \\
MCC \\
Cutaneous lymphomas
\end{tabular}

SCC, squamous cell carcinoma; BCC, basal cell carcinoma; MCC, merkel cell carcinoma

colonization of pityrosporum ovale in the skin. ${ }^{7}$ In these patients, seborrheic dermatitis is more difficult to treat than the general population. ${ }^{4,7}$ The acne-like rashes triggered by steroids and m-TOR inhibitors may also be seen. ${ }^{4,8}$ The organ recipients use antimicrobial, antihypertensive and other systemic drugs as well as immunosuppressive therapies. These drugs can cause various atypical drug reactions that are difficult to diagnose, which may be mildly or potentially life-threatening. In this case, skin biopsy, laboratory examinations for the exclusion of other possibilities, and sometimes possible discontinuation of the suspected drug are tried to reach the diagnoses.

\section{Infectious skin lesions}

Various viral, bacterial, fungal and parasitic infections are more common in the organ recipients due to immunosuppressive treatments. The clinical findings of these infections are atypical and more common and tend to be resistant to classical therapies. In these patients, infections caused by some opportunistic pathogens, which are rarely the causative agents of the diseases in healthy individuals, should be kept in mind. Virus infections such as cytomegalovirus (CMV), Epstein-Barr virus (EBV) and Human Herpesvirus (HHV) -6, 7, 8 can be seen clinically in addition to systemic findings as well as non-specific skin rashes. The organ transplant patients are given prophylaxis treatment for CMV according to their serology.

The frequency and number of warts associated with Human papillomavirus (HPV) increase in these patients. In one study, the prevalence of viral warts in patients with renal transplantation was $50 \%$ in the first year and more than $90 \%$ in five years. ${ }^{9}$ Warts tend to be numerous in transplant patients and are resistant to treatment. Due to the relationship between HPV and anogenital cancer and SCC, the warts of the patients should be treated without delay. Currently, there are recently developed HPV vaccines to prevent genital warts and HPV-associated genital cancers, but there is no vaccine yet to prevent HPVassociated epithelial cancers in the skin. However, in immunocompromised mice with cyclosporine treatment, successful results have been obtained for the prevention of wart development and skin cancers for the first time after vaccination with skin type HPV-like proteins. ${ }^{10}$ In this patient group, there is no data for the efficacy and safety of genital HPV vaccine administration. Until a new HPV vaccine is produced, there is a need for studies investigating the use of existing genital HPV vaccines in this patient group in the light of the theoretical knowledge that it may provide cross-protection against other types.

The common and atypical lesions can be seen with poxvirus, the causative agent of molluscum contagiosum. Herpes virus (HSV-1, HSV-2, VZV, HHV$6,7,8)$ infections and reactivations are other common groups of viral infections that are frequently seen 
in immunosuppressed patients. More common and necrotizing lesions may be seen in these patients with herpes virus infections, while life-threatening systemic spread may also be observed. ${ }^{6}$ If patients are not receiving prophylaxis treatment for CMV, acyclovir prophylaxis is recommended to prevent HSV and VZV infections. ${ }^{11}$ It is recommended to administer the herpes zoster vaccine (Zostavax $\mathrm{TM}$ ) in order to prevent herpes zoster complications if the patient is over 60 years old or varicella IgG titer is low. Herpes zoster vaccine should be administered at least one month before the transplant due to living vaccination; post-transplant administration is contraindicated due to the immunosuppressants therapies. ${ }^{4}, 11$ A case of trichodysplasia in a 5-year-old child with papovavirus infection which treated with local cidofovir and systemic valganciclovir treatment was reported one year after heart transplant. ${ }^{12}$

Impetigo and folliculitis caused by bacteria such as staphylococcus and streptococcus are common bacterial infections in these patients. Rarely, the infections caused by tuberculosis and other atypical mycobacteria may occur with atypical skin findings such as abscess-like nodules and ulcerative lesions. ${ }^{13}$

In transplant patients superficial fungal infections such as mucocutaneous candidiasis, pityriasis versicolor, hand, foot, and nail fungal infections are seen in higher incidence rate. Various and atypical skin manifestations may be seen in these patients secondary to Aspergillus and other systemic fungal infections. Rare species of fungi, such as Cryptococci, can also cause widespread infections in immunocompromised patients. ${ }^{6,14,15}$

The scabies is caused by a mite called Sarcoptes scabiei, as with all immunosuppressed patients, it can cause a more severe form of the disease called Norwegian scabies and can mimic many inflammatory skin diseases. ${ }^{16}$

\section{Side effects of immunosuppressive drugs on skin and appendages}

The immunosuppressive therapies used to prevent tissue rejection in organ transplants are life-saving in these groups and increase survival. However, they leave the transplant patients vulnerable to infections and tumorigenesis. These drugs cause susceptibility to infection and neoplasia and also make unique changes to the skin.

The glucocorticoids cause skin changes such as bad wound healing, thinning of the skin, striae, acne, telangiectasia, increased hair growth, ecchymosis. Cyclosporine causes gingival hyperplasia and hair growth, while tacrolimus causes hair loss. ${ }^{17}, 18$ Azathioprine increases sensitivity to ultraviolet rays and $\mathrm{m}$-TOR inhibitors can cause acne, aphthous stomatitis, and nail changes while disrupting wound healing. ${ }^{13,19}$

\section{Neoplastic skin lesions}

In patients after solid organ transplant, especially the risk of epithelial skin cancers (SCC, BCC, MCC) and kaposi sarcoma increase. SCC and BCC account for $90 \%$ of skin cancers after organ transplantation and more than $40 \%$ of all cancers. ${ }^{20}$ Skin cancers (except BCC) tend to behave more aggressively in transplant patients than in the normal population as well as they show increased incidence. ${ }^{21}$

\section{Squamous cell carcinoma (SCC) and its precursors}

It is the most common type of cancer and skin cancer in organ transplant patients. In various studies, the frequency in transplant patients was found to be 65250 times higher than in normal population. ${ }^{21-23}$ SCC tends to be multifocal on transplant patients and to have more metastases. ${ }^{6,20,21}$ The mean post-transplant occurrence time was reported to be 3-10 years. ${ }^{21}$ The chronic ultraviolet radiation exposure, light skin color, intense immunosuppressive treatment, and genetic predisposition are risk factors. ${ }^{24,} 25$ Male sex, being older at the time of transplant, and the time after transplant are independent risks for SCC and BCC in these patients. ${ }^{21}$ The lesions usually arise in sunexposed areas. The risk of development of invasive SCC from intraepidermal precursor lesions such as actinic keratosis (AK) and Bowen's disease in healthy individuals is approximately $10 \%$, while it is $30 \%$ in 
these patients. ${ }^{24}$

The diagnosis of $\mathrm{AK}$, Bowen disease, invasive epithelial tumors and benign epithelial tumors in transplant patients may be more difficult than in normal individuals. AK may be present with a much wider area involvement, sometimes as a "field cancerization". Therefore, it is necessary to be more skeptical and decisive when taking a biopsy decision for histopathological examination in these patients. Keratoacanthoma is a well-differentiated type of SCC. Although it may spontaneously regress in normal individuals, it tends to progress more in transplant patients. Therefore, keratoacanthoma in transplant patients should be treated like other forms of SCC. ${ }^{21}$

HPV is associated with an increased risk of SCC and anogenital carcinoma. ${ }^{26}$ Therefore, all genital and nongenital warts should be treated selectively before and after transplantation.

In these patients; SCC lesions should be totally excised by means of Mohs surgery or stepwise bordercontrolled surgery. The sentinel lymph node sampling is recommended in transplant patients with highrisk SCC. ${ }^{21}$ In patients with multiple SCC lesions, multifocal Bowen disease, and metastatic SCC, the physician should consider reducing the dose of immunosuppressive therapy and reorganizing the treatment. $^{20,21}$

\section{Basal cell carcinoma (BCC)}

BCC is the second most common cancer in transplant patients. There is a 10-16-fold increased risk in transplant patients than in normal population. ${ }^{20}$ BCC occurs approximately in 5-11 years after transplant. ${ }^{27}$ The most common skin cancer in the community is BCC, while it is SCC in transplant patients. The clinical and histopathological behavior of BCC, unlike SCC, is not different or more aggressive in transplant patients than in normal populations. ${ }^{6}$

\section{Merkel cell carcinoma (MCC)}

MCC is a rare malignant neoplasm with a poor prognosis, also called primary cutaneous neuroendocrine carcinoma. Ultraviolet (UV) exposure, age, chronic lymphocytic leukemia, and immunosuppression are risk factors for MCC development. Although it has been reported that it develops in $7-8 \%$ of organ transplant patients, this rate is higher than expected and exaggerated. ${ }^{28}$ With the data obtained, a 5-10fold increase in frequency is mentioned. It occurs in average 7.6 years after transplant. ${ }^{29}$ It is usually clinically manifested by an asymptomatic, rapidly growing red-blue, sometimes ulcerated, dome-shaped nodule. In one study, one-third of the MCCs were had been misdiagnosed as a cyst in the clinical practice. ${ }^{30}$ The studies and experiences show the importance of a much more skeptical approach to new skin lesions developing in these patients.

In 2008, a new polyomavirus called Merkel cell polyomavirus was detected in the biopsy materials of MCC case. ${ }^{31}$ Merkel cell polyomavirus is thought to contribute to MCC formation. MCC tends to spread to local and distant lymph nodes in $68 \%$ of patients. Therefore, the sentinel lymph node sampling is recommended in MCC cases. ${ }^{21}$ The five-year survival rate is less than $50 \% .^{21,32}$ The treatment approach is wide local excision, adjuvant radiotherapy, and multiagent chemotherapy in metastatic disease. ${ }^{21}$

\section{Skin appendage tumors}

It is a benign or malignant epithelial tumor that develops from the eccrine or apocrine sweat glands of the skin, sebaceous glands or the hair follicle. In a retrospective study performed between 1993 and 1998, 23 appendageal tumors were found in 21 of 650 patients undergoing transplant. The study shows that $3 \%$ of the organ transplant patients developed skin appendage tumors and this rate is higher than in normal population. In addition, malignant tumors were overrepresented in transplant patients $(43 \%$ of transplant tumors). ${ }^{33}$ Pilomatrixoma, sebaceous adenoma, and eccrine poroma are more common tumors of benign skin appendage. The most common malignant skin appendage tumor in transplant patients is sebaceous carcinoma. ${ }^{21}$ Other skin cancers such as SCC and BCC were also detected in $71 \%$ of transplant 
patients with skin appendage tumors in a study. During the mean follow-up period of 3.4 (2-7) years, there was no recurrent and metastasis of skin appendage tumors in transplant patients. ${ }^{33}$

\section{Melanoma}

Melanoma has been shown to increase 2-8 times in transplant patients in different studies..$^{21,34,35}$ Melanoma accounted for $6 \%$ of skin cancer in transplant patients and this rate was found to be higher in children (12-15\%) and African-American (17\%) patients. ${ }^{35}$ Melanoma occurs more frequently in young patients and males, with an average of 4-5 years after transplant. ${ }^{21,35,36} \mathrm{In}$ transplant patients, the intermittent sun exposure, light skin color, presence of multiple dysplastic nevus and family history of melanoma are risk factors.

The clinical features of melanoma are not different in transplant patients compared to normal individuals. Early stage melanoma (Breslow $<2 \mathrm{~mm}$ ) has the same prognosis in these patients, whereas advanced stage melanoma (Breslow $>2 \mathrm{~mm}$ ) is more aggressive in transplant patients. ${ }^{21,37}$

The sentinel lymph node biopsy should be performed in patients with Breslow thickness higher than 0.75 and with mitotic index $>1 / \mathrm{mm}^{2}$. Although it is recommended to reduce the dose of immunosuppressive therapy in transplantation patients who have developed melanoma, other treatment options are determined by the tumor stage and the presence of metastasis. ${ }^{21}$

\section{Kaposi's sarcoma (KS)}

Kaposi's sarcoma is a rare vascular tumor. However, its incidence has increased 400-500 times in transplant patients, and it constitutes $5.7 \%$ of all cancers. ${ }^{21,36}$ It occurs on an average of 13 months after transplantation, earlier than non-melanoma skin cancers. ${ }^{6,36}$

HHV-8 can be demonstrated in all epidemiological and clinical types and all histological stages of KS by PCR or immunohistochemistry. ${ }^{21,} 38$ HHV-8 can be transmitted through sexual intercourse, blood, other body fluids, and organ transplants. In transplant patients, KS develops by reactivation of the latent virus, as well as the transmission of HHV-8 from the transplanted organ. ${ }^{21}$

KS carries the risk of spreading to the skin and internal organs and leading to death. The skin and mucosal lesions are seen in more than $75 \%$ of patients who developed KS after organ transplantation, and 25$50 \%$ of internal organs may be involved. ${ }^{36,38}$ The 5-year survival rate of iatrogenic KS after transplantation is around $69 \%{ }^{21}$

In KS patients, the treatment is primarily to reduce and modify immunosuppressive therapy. The complete remission rate has been reported with 25$30 \%$ reduced dose of immunosuppressive treatment without additional treatment. ${ }^{39}$ It has been shown that replacing treatment with $\mathrm{m}$-TOR inhibitors, besides reducing the dose of immunosuppressive drugs, leads to improvement in KS lesions. ${ }^{40}$ Other advanced treatment modalities include excision, radiotherapy, intra-lesion bleomycin, anthracyclines, interferon, and local imiquimod. ${ }^{21}$

\section{Soft tissue tumors-sarcomas}

Atypical fibroxanthoma, malignant fibrous histiocytoma and leiomyosarcoma of the skin are rarely reported sarcomas in transplant patients except for KS. ${ }^{6,21}$

\section{Cutaneous lymphomas}

Lymphoid diseases are observed at 1-5\% after organ transplant. ${ }^{41}$ The heart, lung and liver recipients carry more risk than kidney recipients. ${ }^{21}$ Very few primary skin lymphomas have been reported in organ recipients. Cutaneous lymphomas are seen 5-8 years after transplant. ${ }^{42} 70 \%$ of reported cutaneous lymphomas are $\mathrm{T}$ cell-derived and $30 \%$ are derived from B cells. ${ }^{21}$ Most post-transplant B cell lymphomas are associated with EBV. ${ }^{21}$ The prognosis of cutaneous lymphomas seen in transplant patients varies according to the type of lymphoma and the immune status of the patient. 


\section{General principles of skin cancer man- agement in transplant patients}

\section{Sun protection}

UV exposure is the most important preventable cause of melanoma and non-melanoma skin cancer. In order to prevent skin cancers, sun protection is one of the most effective measures in the community and in immunocompromised patients.

The patients should be advised to use a high-protective sunscreen against UV-A and UV-B. The sunscreen creams should be applied at an amount of $2 \mathrm{mg} / \mathrm{cm}^{2}$ to the areas which are exposed to the sun at 365 days of the year, including the winter season. Additional protective measures, such as clothing and hats, should also be recommended. Patients should be advised not to be outdoors during the morning between 11 am and $3 \mathrm{pm} .^{6}$

It is recommended to follow the vitamin D levels of the patients against the risk of decreasing the vitamin $D$ level theoretically. Serum 25 OH-D3 should be higher than $75 \mathrm{nM}$ or $30 \mathrm{ng} / \mathrm{ml}$. The values below $30 \mathrm{nM}$ or 12 $\mathrm{ng} / \mathrm{ml}$ are considered to be severe vitamin D deficiency. The patient is required to take complementary treatment according to the state of vitamin D.

\section{Reducing and changing the dose of}

\section{immunosuppressive therapy}

The type, dose, and duration of immunosuppressive therapy are closely related to the development of skin cancer and infection. In order to prevent and treat skin disease, the gain-loss balance should be evaluated individually in each patient without causing tissue rejection while reducing or modifying immunosuppressive therapy. The patient's age, treatment, disease-specific risks, organ tissue HLA match, time elapsed after transplantation, and patient's history of tissue rejection should be considered. ${ }^{43}$

Immunosuppressive therapy can be modified by reducing the dosage of current drugs or "triple therapy" can be switched to "dual therapy". As studies have shown increased malignancy risk with calcineurin inhibitors, replacement of these therapies with m-TOR inhibitors may be another option. Azathioprine causes not only cancer with its immunosuppressive effect but also increases the risk of skin cancer by increasing the sensitivity to ultraviolet rays. ${ }^{13}$ If the patient has a moderate or high risk of SCC and the transplanted organ functions are stable, the replacement of azathioprine treatment with other anti-metabolite mycophenolate salts is considered. ${ }^{44}$ Although mycophenolate salts have been shown to reduce the risk of skin cancer, physicians should be kept in mind that it is a strong immunosuppressant and increases the risk of infection. Anti-tumoral and anti-viral effects of $\mathrm{m}$-TOR inhibitors in vivo and in vitro have been demonstrated. ${ }^{6,13,21}$ The studies have shown that reduction of calcineurin inhibitor dose or adding $\mathrm{m}$-TOR inhibitors to the treatment or using $\mathrm{m}$-TOR inhibitor instead of the direct calcineurin inhibitor, decreased cancer formation. ${ }^{45}$ Again, in these studies, it was observed that the addition of m-TOR inhibitors to the treatment significantly increased organ rejection, but it was important to make these treatment changes in appropriate patients. The m-TOR inhibitor is an appropriate immunosuppressive treatment option in KS patients because of the direct therapeutic effects and allows to reduce the dose of other immunosuppressive therapies. In patients with moderate and high-risk SCC and KS, it is recommended to add $\mathrm{m}$-TOR inhibitors if the organ functions are stable. ${ }^{43}$ In a study, no significant difference was found between the rapid cut-off of corticosteroid treatment after transplant and high-dose long-term use in terms of organ transplant. ${ }^{46}$ Various studies are underway in terms of immunosuppressive regimens that do not contain steroids and calcineurin inhibitors, and new treatment protocols that are not oncogenic or does not weaken the immune system.

\section{Preventive treatments for skin cancer}

Acitretin, which has an important role in the treatment 
of some dermatological diseases, is a systemic retinoid agent that has been shown to be a preventive agent in SCC formation in patients with transplant and in other patients. The reduction rate of SCC in various studies has reached $85 \%{ }^{43,47,48}$ Systemic retinoid use is recommended for patients with moderate and high risk SCC, metastatic SCC, systemic SCC, annually one or more SCC occurrence, multiple SCC in the head and neck region, sudden and multiple keratoacanthoma output, history of SCC and leukemia/lymphoma, intense actinic keratoses in one area, if organ functions are stable (level of evidence A) (Table 2).47, 48

Table 2. Patients appropriate for systemic retinoid use

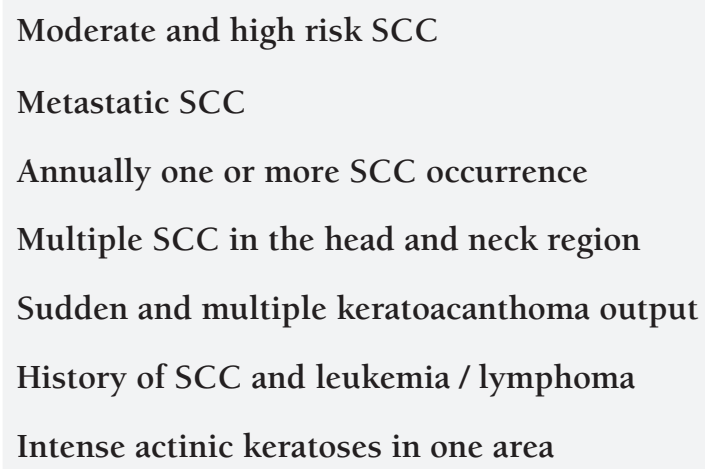

Skin cancer prevention treatment should be continued for a lifetime as well as the current tumor treatment. Systemic retinoid therapy can be added to reduce morbidity and mortality in high-risk and metastatic patients who cannot be operated. ${ }^{43}$ The use of acitretin is useful in the treatment of common viral warts in this patient group as well as in anti-tumoral activity. ${ }^{6}$

Acitretin is usually used at a dose of $0.4 \mathrm{mg} / \mathrm{kg} /$ day. Most authors recommend that the dose should be started at $10 \mathrm{mg} /$ day every other day and by increasing the dose gradually every 2-4 weeks. If the final dose cannot be tolerated by the patient, it is recommended that the previous tolerable dose is continued. ${ }^{43}$ The typical dose-dependent and reversible side effects are mouth dryness and hair loss. For the first two months of treatment transaminases, creatinine and lipids should be examined every two weeks, then once a month. It should not be used in combination with tetracycline, methotrexate and other A vitamins. Fertile women should use effective contraception for three years after the treatment is completed. Therefore, in women with childbearing potential, isotretinoin, another retinoid derivative, which is safe for pregnancy after one month of treatment termination, is preferred.

Multiple fast-growing aggressive SCC clearances have been reported with rebound effect when retinoid therapy is discontinued. ${ }^{49}$ In cases where retinoid therapy is to be discontinued, it is recommended to slowly reduce the dose to prevent this rebound effect. $^{43,47}$

Currently, studies are ongoing about treatment of advanced stage SCC in transplant patients, investigating the effectiveness of capecitabine and EGFR inhibitor use or $\alpha$-MSH analogues as a treatment option for systemic sunscreen. ${ }^{50}$

\section{References}

1. Alam M, Brown RN, Silber DH, et al. Increased incidence and mortality associated with skin cancers after cardiac transplant. Am J Transplant 2011;11:1488-97.

2. Metchnikoff $\mathrm{C}$, Mully $\mathrm{T}$, Singer $\mathrm{J}$, et al. The $7^{\text {th }}$ edition AJCC staging system for cutaneous squamous cell carcinoma accurately predicts risk of recurrence for heart and lung transplant recipients. J Am Acad Dermatol 2012;67:829-35.

3. Otley CC, Hirose R, Salasche SJ. Skin cancer as a contraindication to organ transplantation. Am J Transplant 2005;5:2079-84.

4. Hofbauer GFL, Freiberger SN, Iotzova-Weiss G, Shafaeddin B, Dziunycz PJ. Organ transplantation and skin-principles and concepts. Curr Probl Dermatol 2012;43:1-8.

5. Ali FR, Samarasinghe V, Russell SA, Lear JT. Increasing capacity for skin surveillance in a transplant review clinic. Transplantation 2014;97:48-50.

6. Ulrich C, Arnold R, Frei U, et al. Skin changes following organ transplantation: an interdisciplinary challenge. Dtsch Arztebl Int 2014;111:188-94. 
7. Lally A, Casabonne D, Newton R, Wojnarowska F. Seborrheic dermatitis among Oxford renal transplant recipients. J Eur Acad Dermatol Venereol 2010;24:561-4.

8. Mahe E, Morelon E, Lechaton S, et al. Acne in recipients of renal transplantation treated with sirolimus: clinical, microbiologic, histologic, therapeutic, and pathogenic aspects. J Am Acad Dermatol 2006;55:139-42.

9. Kralund $H$, Broesby-Olsen $S$, Bistrup $C$, et al. Substantial effect of topical cidofovir $1 \%$ on recalcitrant warts in a renal-transplanted adolescent: a case report. Transplantation 2011;91:e52-4.

10. Vinzon SE, Braspenning-Wesch I, Muller M, et al. Protective vaccination against papillomavirusinduced skin tumors under immunocompetent and immunosuppressive conditions: a preclinical study using a natural outbred animal model. PLoS Pathog 2014;10:e1003924.

11. Shiley K, Blumberg E. Herpes viruses in transplant recipients: HSV, VZV, human herpes viruses, and EBV. Hematol Oncol Clin North Am 2011;25;17191.

12. Stephan C, Kurban M, Khalil S, Bitar F, El-Rassi I, Assy J. Viral-associated trichodysplasia spinulosa in a paediatric cardiac transplant recipient. Clinical and Clin Exp Dermatol 2020;45:244-6.

13. Ozoguz P, Karaca S. Post-transplantation oncological and dermatological problems. Turkiye Klinikleri J Gen Surg-Special Topics 2013;6:142-9.

14. Hogewoning AA, Goettsch W, van Loveren H, de Fijter JW, Vermeer BJ, Bouwes Bavinck JN. Skin infections in renal transplant recipients. Clin Transplant 2001;15:32-8.

15. Ponticelli C, Bencini PL. Nonneoplastic mucocutaneous lesions in organ transplant recipients. Transpl Int 2011;24:1041-50.

16. Cakmak SK, Gonul M, Gul U, Unal T, Daglar E. Norwegian scabies in a renal transplant patient. Australas J Dermatol 2008;49:248-9.

17. Webb NJA, Coulthard MG, Trompeter RS, et al. Correlation between finger-prick and venous ciclosporin levels: Association with gingival overgrowth and hypertrichosis.Pediatr Nephrol 2007;22:2111-8.

18. Tricot L, Lebbe C, Pillebout E, et al. Tacrolimusinduced alopecia in female kidney-pancreas transplant recipients. Transplantation 2005;80:1546-9.
19. Campistol JM, de Fijter JW, Flechner SM, Langone A, Morelon E, Stockfleth E. MTOR inhibitorassociated dermatologic and mucosal problems. Clin Transplant 2010;24:149-56.

20. Euvrard S, Kanitakis J, Claudy A. Skin cancers after organ transplantation. $\mathrm{N}$ Engl J Med 2003;348:1681-91.

21. Kempf W, Mertz KD, Kanitakis J, Hofbauer GFL. Critical skin cancer in organ transplant recipients-a dermatopathological view. Curr Probl Dermatol 2012;43:18-35.

22. Jensen P, Hansen S, Moller B, et al. Skin cancer in kidney and heart transplant recipients and different long-term immunosuppressive therapy regimens. J Am Acad Dermatol 1999;40:177-86.

23. Lindelof B, Sigurgeirsson B, Gabel H, Stern RS. Incidence of skin cancer in 5356 patients following organ transplantation. Br J Dermatol 2000;143:513-9.

24. Surber C, Pittelkow M, Lautenschlager S. Photoprotection in transplant recipients. Curr Probl Dermatol 2012;43:171-96.

25. Ulrich C, Kanitakis J, Stockfleth E, Euvrard S. Skin cancer in organ transplant recipients - Where do we stand today? Am J Transplant 2008;8:2192-8.

26. Bouwes Bavinck JN, Neale RE, Abeni D, et al. Multicenter study of the association between betapapillomavirus infection and cutaneous squamous cell carcinoma. Cancer Res 2010;70:9777-86.

27. Mertz KD, Proske D, Kettelhack N, et al. Basal cell carcinoma in a series of renal transplant recipients: Epidemiology and clinicopathologic features. Int J Dermatol 2010;49:385-9.

28. Buell J, Trofe J, Hanaway MJ, et al. Immunosuppression and Merkel cell cancer. Transplant Proc 2002;34:1780-1.

29. Koljonen V, Kukko H, Tukiainen E, et al. Incidence of Merkel cell carcinoma in renal transplant recipients. Nephrol Dial Transplant 2009;24:3231-5.

30. Heath M, Jaimes N, Lemos B, et al. Clinical characteristics of Merkel cell carcinoma at diagnosis in 195 patients: the AEIOU features. J Am Acad Dermatol 2008;58:375-81.

31. Feng H, Shuda M, Chang Y, Moore PS. Clonal integration of a polyomavirus in human Merkel cell carcinoma. Science 2008;319:1096-100.

32. Lemos B, Storer B, Iyer J, et al. Pathologic nodal evaluation improves prognostic accuracy in Merkel 
cell carcinoma: analysis of 5823 cases as the basis of the first consensus staging system. J Am Acad Dermatol 2010;63:751-61.

33. Harwood C, McGregor J, Swale VJ, et al. High frequency and diversity of cutaneous appendageal tumors in organ transplant recipients. J Am Acad Dermatol 2003;48:401-8.

34. Kasiske BL, Snyder JJ, Gilbertson DT, Wang C. Cancer after kidney transplantation in the United States. Am J Transplant 2004;4:905-13.

35. le Mire L, Hollowood K, Gray D, Bordea C, Wojnarowska F. Melanomas in renal transplant recipients. Br J Dermatol 2006;154:472-7.

36. I Penn. Malignant melanoma in organ allograft recipients. Transplantation 1996;61:274-8.

37. Brewer J, Christenson L, Weaver AL, et al. Malignant melanoma in solid transplant recipients: collection of database cases and comparison with surveillance, epidemiology, and end results data for outcome analysis. Arch Dermatol 2011;147:790-6.

38. Robin YM, Guillou L, Michels JJ, Coindre JM. Human herpesvirus 8 immunostaining: a sensitive and specific method for diagnosing Kaposi sarcoma in paraffin-embedded sections. Am J Clin Pathol 2004;121:330-4.

39. Pedagogos E, Nicholls K, Dowling J, Becker G. Kaposi's sarcoma post renal transplantation. Aust N Z J Med 1994;24:722-3.

40. Hofbauer GFL, Bavinck JNB, Euvrard S. Organ transplantation and skin cancer: basic problems and new perspectives. Exp Dermatol 2010;19:473-82.

41. Beynet D, Wee S, Horwitz S, et al. Clinical and pathological features of posttransplantation lymphoproliferative disorders presenting with skin involvement in 4 patients. Arch Dermatol 2004;140:1140-6.

42. Yurtsever H, Kempf W, Laeng RH. Posttransplant $\mathrm{CD}_{30}+$ anaplastic large cell lymphoma with skin and lymph node involvement. Dermatology 2003;207:107-10.

43. Schreve B, Anliker M, Arnold A, et al. Preand posttransplant management of solid organ transplant recipients: risk-adjusted follow-up. Curr Probl Dermatol 2012;43:57-70.

44. Hofbauer GFL, Attard NR, Harwood CA, et al. Reversal of UVA skin photosensitivity and DNA damage in kidney transplant recipients by replacing azathioprine. Am J Transplant 2012;12:218-25

45. Campistol JM, Gutierrez-Dalmau A, Torregrosa JV.
Conversion to sirolimus: a successful treatment for posttransplantation Kaposi's sarcoma. Transplantation 2004;77:760-2.

46. Vincenti F, Schena FP, Paraskevas S, Hauser IA, Walker RG, Grinyo J. A randomized, multicenter study of steroid avoidance, early steroid withdrawal or standard steroid therapy in kidney transplant recipients. Am J Transplant 2008;8:307-16.

47. Bavinck JNB, Tieben LM, van der Woude FJ, et al. Prevention of skin cancer and reduction of keratotic skin lesions during acitretin therapy in renal transplant recipients: A double-blind, placebocontrolled study. J Clin Oncol 1995;13:1933-8.

48. Harwood CA. Low-dose retinoids in the prevention of cutaneous squamous cell carcinomas in organ transplant recipients a 16-year retrospective study. Arch Dermatol 2005;141:456-64.

49. George R, Weightman W, Russ GR, Bannister KM, Mathew TH. Acitretin for chemoprevention of non-melanoma skin cancers in renal transplant recipients. Australas J Dermatol 2002;43:269-73.

50. Zecher D, SteigerJ. Future trends in organ transplant recipients-important issues for dermatologists. Curr Probl Dermatol 2012;43:71-80. 